\author{
Krishna Prasad Upadhyay*
}

\begin{abstract}
Every business entity should be able to enhance their competitive strength through achieving the financial goals. Financial statement analysis should be adopted to appraise the financial performance of the concerned companies. Information and results obtained from financial analysis are important to all stakeholders. Interest of the different stakeholders is conflicting. Out of different stakeholders, managements of the companies worry about their financial performance. So, in this paper, an attempt to analyse the financial performance of Pokhara Finance Company and Annapurna Finance Company has been made.
\end{abstract}

FINANCE COMPANIES ARE THOSE intermediaries, which link the savers and users of capital. They collect small and scattered saving of the individuals and mobilize it in the productive sectors in the form of investment or loan. Previously Finance Company Act, 2042 used to govern finance companies in Nepal. Now, the Bank and Financial Institutions Ordinance, 2004 governs all types of banks and financial institutions.

Since the restoration of democracy in 1990, number of finance companies has grown drastically in Nepal. Out of them, Pokhara Finance Company Limited (POFIL) and Annapurna Finance Company Limited (AFCL) are in operation in Pokhara. There are various stakeholders having their own interest in the performance of the finance companies. The performance of the finance companies largely depends upon the quality of the management. Therefore, the management of the finance company would be interested in every aspect of its financial statement analysis. It is their overall responsibility to see that the resources of the company are used most effectively and efficiently, and the financial condition of the company is sound.

Financial statement analysis is a technique of answering various questions regarding the performance of the firm in the past, present and future. The analysis enables financial managers to recommend the steps to be taken for the correction of faults. So, the objectives of this study are to analysis and compare the past and present performance of POFIL and $\mathrm{AFCL}$, to forecast the future position of the POFIL and AFCL, and to recommend the corrective actions to the management of POFIL and AFCL.

\title{
1. Methods of the Study
}

\subsection{Data Management}

This study has not taken up all the finance companies established in Pokhara. Using the stratified sampling technique two finance companies- POFIL and AFCL-were selected as study units of this study. This study is specially based on the secondary data. The required financial data were extracted from the financial statements of the selected companies. The

${ }^{*}$ Mr. Upadhyay is Course Contract Teacher, Faculty of Management, PNC, Pokhara. 


\section{The Journal of Nepalese Business Studies}

qualitative information was collected by visiting the Head Office of selected companies. In addition, discussion with the concerned official was held and qualitative information required to back up the quantitative data was explored during the discussion. This study covers the time horizon of the fiscal year 2055/2056 to 2059/2060.

\subsection{Financial Tools Used in the Study}

This study has used different types of financial ratios to check up the financial performance of the selected finance companies. Basically these financial ratios-solvency ratio, liquidity ratio, efficiency ratio, profitability ratio and valuation ratio-are used extensively in this study. Under the solvency ratio group, total debt to net worth, debt to equity, fixed assets to long- term funds and net worth to total liabilities ratios are used to analyse the solvency position the selected finance companies. In the same manner, cash reserve, primary reserve, secondary reserve, current ratio, and acid test ratio are analyzed to examine the liquidity position of the selected companies. Similarly, cash flow to debt and capitalization, interest coverage ratio, credit to deposit ratio, and credit investment to deposit ratio are used to analyze the operating efficiency of the companies. Profitability of the selected companies also has been analyzed. Different measures like return on investment, return on equity, return on assets, earning per share, dividend per share, and asset utilization ratio are used to assess the profitability of the companies. Finally, market related ratios-price earning ratio, dividend payout ratio, dividend yield ratio, market value to book value are analyzed to examine the performance of companies in market environment.

\section{Data Analysis and Interpretation}

\subsection{Solvency Ratios}

It is calculated to examine the financial leverage of the company. It is also called appraisal of long term financial soundness of the company. The worked out ratios of POFIL and AFCL for last five fiscal years are given in Appendix 1. Relative to the normal standard ratio of 1.5:1, total debt to net worth ratios of both companies are extremely high. The POFIL has 9.46:1, 7.28:1, 6.15:1, 7.63:1, and 8.16:1 from the fiscal year 2055/056 to 2059/060. The total debts to net worth ratios are normally fluctuating. Likewise, the total debt to net worth ratios in AFCL from the fiscal year 2055/056 to 2059/060 are 9.31:1,7.92:1,6.47:1,6.86:1 and 4.22:1. These ratios are slightly in decreasing trend. Thus, the net worth was not sufficient to support the total debt.

The normal standard of debt equity ratio is $2: 1$. Both the companies have used more amount of debt during the fiscal year 2055/056 to 2059/060. The POFIL has the ratios ranging from 7.3:1 to $9.46: 1$ and the AFCL has the ratios from 4.22:1 to 10.42:1. The trend of ratio in POFIL is slightly fluctuated and AFCL is in decreasing trend. Both companies have used high portion of debt in their capital structure.

The amount of fixed assets in both companies is not sufficient to bear the burden and claim of long term fund suppliers. The normal standard of fixed assets to long-term fund is $1: 1$ whereas the ratios in POFIL range from $0.01: 1$ to $0.06: 1$ and AFCL do from $0.1: 1$ to $0.08: 1$ during the study period. Thus, the investment of long-term fund in fixed assets is extremely low in both the companies.

The normal standard of net worth to total liability ratio is $1: 1$. But the ratios of POFIL range from $0.12: 1$ to $0.25: 1$ and AFCL do from $0.12: 1$ to $0.45: 1$ during the study period. In both companies, the ratio is in decreasing trend. These ratios indicate that the outsiders claim on the assets of the companies is more than the owners. 
Financial Analysis of Finance Companies

\subsection{Liquidity Ratios}

It is calculated to examine the liquidity position of the company. Liquidity ratio measures the short-term solvency indicating the company's ability to meet the short-term obligations. Calculated financial ratios that show the liquidity position of the selected companies are given in panel (b) of Appendix 1. The cash reserve ratio of POFIL is in the range of $0.0005: 1$ to $0.0350: 1$. These ratios indicate that the POFIL have not maintained sufficient cash balance. Cash reserve ratios of $A F C L$ are in the range of $0.003: 1$ to $0.140: 1$. Thus, relative to POFIL, AFCL has higher cash reserve ratio.

The primary reserve ratios of both companies indicate that those had sufficient amount to pay the demand and matured fixed deposits, and others short term obligations. On the other hand, secondary reserve ratios in both companies indicate that marketable securities were strictly supporting against the total deposit liabilities.

The current ratios of both companies are more than the normal standard $(2: 1)$ and acid test ratios also are extremely higher than the normal standard (1:1). These conditions indicate that both companies are failing to mobilize their liquid fund in more profitable sectors.

\subsection{Efficiency Ratios}

The ratios falling in this group measure the efficiency of management in the utilization available. The worked out efficiency ratios are given in panel (c) of Appendix 1. The cash flow to debt and capitalization ratios indicates that total liability has been used efficiently in POFIL and AFCL. But these ratios in POFIL are greater than in AFCL, which indicate that the POFIL had utilized debt and capital more efficiently. These ratios are slightly fluctuating in the range of 0.122 to $0.155: 1$ and $0.113: 1$ to $0.146: 1$ in POFIL and AFCL respectively.

Both interest coverage and cashflow coverage ratios of POFIL are better than that of AFCL. Interest coverage ratios fluctuate in the range of 1.517:1 to $1.904: 1$, and 1.362:1 to 1.733:1 in POFIL and AFCL respectively. The cash flow coverage ratios are within the range of $1.525: 1$ to $1.920: 1$ and $1.369: 1$ to $1.742: 1$ in POFIL and AFCL respectively. Thus, the ratios are slightly fluctuating in both companies. However, both companies have sufficient earning capacity to pay the interest, taxes, and others charges.

The POFIL and AFCL had provided more amounts of loan and advance than the collection of total deposits. Credit creation was good in both companies. The credit and investment was more than the deposit collection, thus both companies had been efficiently mobilizing the fund available to them during the fiscal year 2055/056 to 2059/060.

\subsection{Profitability Ratios}

This is used to test earning power of the company. The profitability ratio measures the operating profitability in terms of profit margin, return on equity return on investment, and reflects the overall efficiency and effectiveness of the management. The financial ratios given in Panel (d) of Appendix 1 depict the profitability of POFIL and AFCL. Return on investment of POFIL ranges from $11.25 \%$ to $21.72 \%$ whereas of AFCL does from $17.17 \%$ to $21.76 \%$ during the study period. Returns on investment of POFIL are slightly more than that of AFCL during the fiscal years 2055/056 to 2059/060. Also the returns on equity of POFIL are more than that of AFCL. The returns of POFIL fluctuate in the range of $29.45 \%$ to $34.45 \%$ and the same do in the range of $11.76 \%$ to $28.78 \%$ during the study period.

The return on assets of POFIL is more than that of AFCL. Return of former company fluctuates from $3.02 \%$ to $4.74 \%$ and latter's does from $2.47 \%$ to $3.93 \%$ during the study period. But the EPS of AFCL is greater than that of POFIL. The EPS of former company ranges from Rs. 63.73 to 88.71 and latter's ranges from Rs 28.00 to 59.47 during the observed fiscal years. 


\section{The Journal of Nepalese Business Studies}

Both companies are trying to adopt constant dividend policy. There is no correlation between EPS and DPS. The AFCL's EPS has increased to Rs. 88.71 in the fiscal year 2056/ 057 but DPS has decreased to Rs. 5.0. On the other hand, the POFIL's EPS has increased to Rs 67.80 in the fiscal year 2059/060 but DPS has decreased to Rs. 25. The EPS of POFIL is fluctuating by slightly higher rate than that of AFCL. Assets utilization ratios of both companies are almost similar during the study period.

\subsection{Valuation Ratios}

The ratios falling in this group examine the market value of the company. The valuation ratios are given in Panel (e) of Appendix 1. P/E ratios of POFIL are better than AFCL during the study period. But, P/E ratios of POFIL are in decreasing trend whereas, in the case of $A F C L$, they are in increasing trend.

Dividend payout ratios of POFIL are greater than that of AFCL. Dividend payout ratios of POFIL are fluctuating by higher rate than that of AFCL. However, POFIL is paying more dividends and AFCL is retaining more earnings in the business. Both companies have not adopted constant dividend policy, and dividend payout is not correlated with earnings in both companies.

The dividend yield of AFCL is slightly greater than that of POFIL. But it is also fluctuating during the observed fiscal years in both companies. There is not consistency of market to book value ratio in both POFIL and AFCL. This ratio also is fluctuating during the study period.

\section{Conclusions}

1. The solvency position of both companies is not sound. The net worth is not sufficient to support the long-term debt, and debt capital is used extremely more than the equity capital. Amount of fixed assets in both companies is not sufficient to bear the burden and claim of long-term suppliers. Thus, the outsiders claim on the assets is more than the owners. The overall trend of solvency position is being positive in the latest years.

2. Based on the cash reserve ratio, primary reserve ratio and secondary reserve ratio, the liquidity position or the capacity to pay short- term obligation of AFCL is better than that of POFIL But based on the current and acid test ratios, POFIL has better liquidity position. This indicates that, from the insiders' view point, POFIL is not so successful to mobilize its fund to the productive sector. Likewise, the POFIL is not able to meet the demand of depositors.

3. The operating efficiency of POFIL is better than that of AFCL. POFIL is able to mobilize its debt and capital in productive sector. Interest coverage and cash flow coverage ratios indicate the better financial position of POFIL. However, the credit creation capacity is good in both companies in aggregate.

4. The better return on investment, return on equity, and return on assets of POFIL indicate that earning power of the POFIL is sound. EPS of AFCL is greater but DPS is lower as compared to the DPS of POFIL. POFIL has retained its earning in productive sector but AFCL is attracting the shareholders having poor economic status. It is puzzling 
that there is no correlation between DPS and EPS of both companies.

5. P/E ratio of POFIL is better than that of AFCL. It brings the higher increment in the share value of POFIL. But P/E ratios of POFIL are in decreasing trend and in the case of AFCL, they are in increasing trend. There is no consistency of dividend payout ratio of both companies during the observed years.

\section{Suggestions}

The results of ratio analysis are the concerned of different stakeholders. Their interests are conflicting nature. The same ratio becomes the green signal to one and red signal to others. It is very difficult to bring their interest in midpoint. In this context, the following suggestions are forwarded to the management of both POFIL and AFCL for their further improvements:

1. The POFIL and AFCL both should raise additional share capital and utilize in purchasing the fixed assets in order to improve their solvency position. Otherwise, deteriorated solvency position would leads to bankruptcy or insolvency. So that, they should not be delay to reform their capital structure.

2. Both companies should increase their cash balance to meet the short-term obligation. They should be ready to pay the demand and short-term fixed depositors. And, other items of current assets should be decreased to utilize their idle funds in more productive sectors. They should try to bring the current and acid test ratios at the normal standard level.

3. They should be ready to utilize their permanent capital in those sectors, which yield comparatively higher rate of returns. Although both companies have earning capacity to pay the interest and other charges, they should enhance their earning capacity to fulfill the interest of shareholders. Both should do further effort for credit creation based on the deposits.

4. Although operating profitability of POFIL is greater than AFCL, it is not at satisfactory level. The fluctuation in return on equity, return on assets and dividend payout ratios adversely affect the image of the companies. So, they should take proper steps to increase or to make such ratios stable on one hand and on the other, they should make consistency on DPS and EPS. Nepalese investors prefer immediate returns, and want higher dividend payout. So, the management should adopt appropriate dividend policy based on the investors' expectations.

5. It is obvious that the value of the company largely depends on the dividend payout ratio, dividend yield of the company. So, the management of the companies should formulate and implement the plans based on these realities.

\section{REFERENCES}

Annapurna Finance Company Ltd. Annual Reports 2055/056 to 2059/060.

Bajracharay, Major Man and others. 2004. An Introduction to Accounting and Auditing. Kathmandu: Buddha Academic Publisher and Distributors Pvt. Ltd.

Pokhara Finance Ltd. Annual Reports, 2055/056 to 2059/060.

Pradhan, Surendra. 2000. Basics of Financial Management, 2nd ed. Kathmandu: Educational Enterprise.

Sharma, Basu. 2058. Corporate Financial Management. Kathmandu: Taleju Prakashan. 


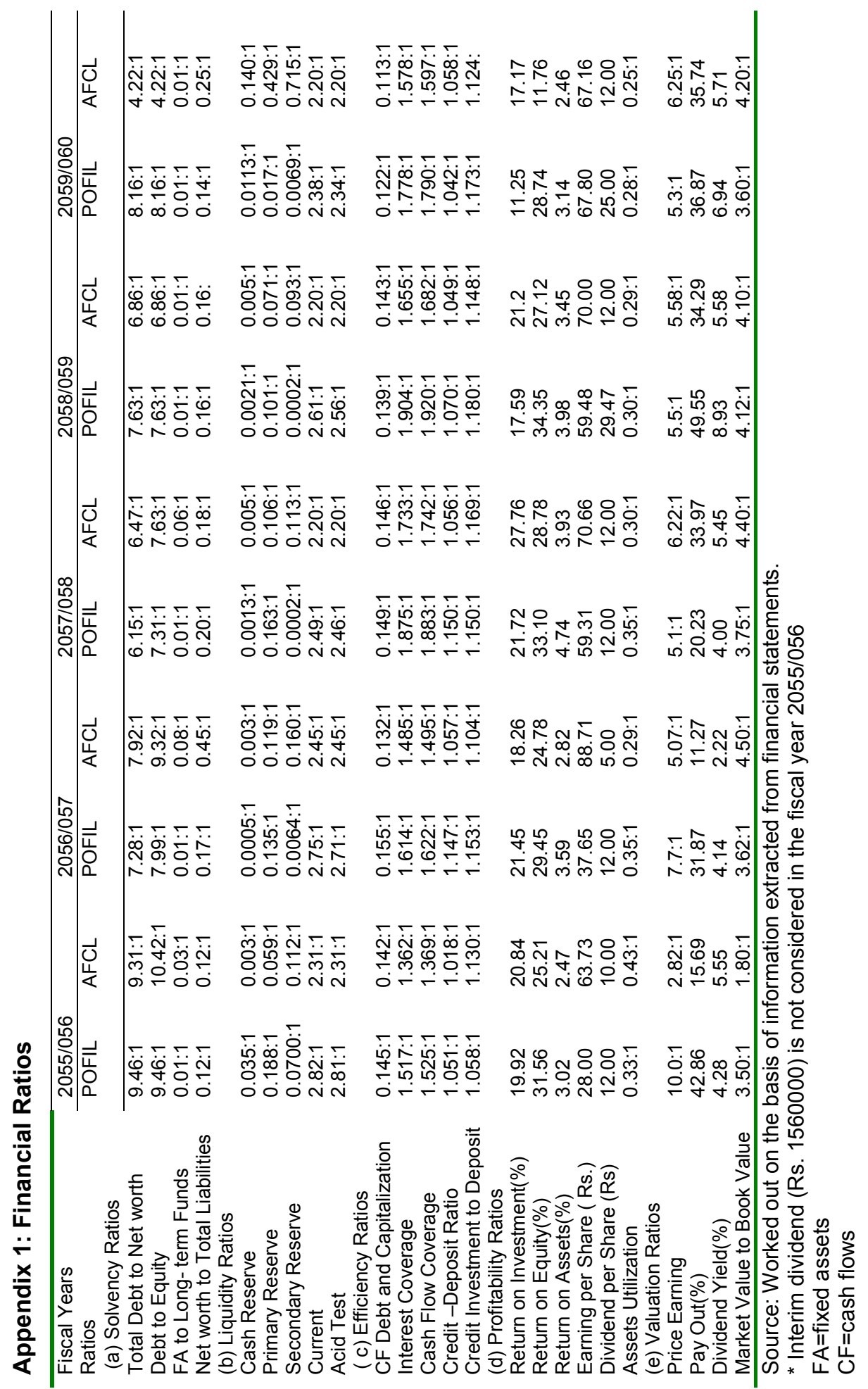

